\title{
Journal of Business and Economics Review
}

Journal homepage: www.gatrenterprise.com/GATRJournals/index.html

J. Bus. Econ. Review 2 (1) 72 - 75 (2017)

\section{Innovation Capability and Customer Relationship Management in Building Competent Young Entrepreneurs}

\author{
Intan Widuri Sakti ${ }^{1 *}$ and Gallang Perdana Dalimunthe ${ }^{2}$ \\ ${ }^{1}$ Universitas Widyatama, Jl. Cikutra No.204A, 40124, Bandung, Indonesia \\ ${ }^{2}$ Universitas Pendidikan Indonesia, Jl. Dr. Setiabudhi No.229, 40154, Bandung, Indonesia
}

\begin{abstract}
Objective - The study aims to learn effect of Innovation Capability and Customer Relationship Management on young entrepreneur's competency.

Methodology/Technique - Questionnaire used for the data collection in this study. The sampling method is probability sampling with simple random sampling technique. The population is all the Marketing students' year 2012, and the calculated sampling is 100 respondents

Findings - From the analysis and explanation using SEM, it is found that Innovation Capability and CRM have a big influence towards young entrepreneurs. Those variables also stimulate them to sharpen their business intuition.

Novelty - The study proves importance of Innovation Capability and CRM on development of entrepreneurs.

Type of Paper: Empirical
\end{abstract}

Keywords: Innovation Capability; CRM; Young Entrepreneurs; Structural Equation Modelling; SEM.

JEL Classification: L26, O32.

\section{Introduction}

Generally, the competency of businesses is growing rapidly nowadays. In order to survive and succeed, a company should become creative and innovative, as well as be ready to face dynamic market changes. Therefore, the customer base is a big issue to fight for so that another company won't take them away. This has led to a condition where the level of competition among companies is so high.

Luk, Yau, Tse, Sin, and Chow (2005) said that CRM is a strategy that company needs to optimize profit by enhancing customer's satisfaction. There was an empirical evidence that shows that a company that applies CRM effectively as a business strategy likely become a market leader. With the increase of customer's satisfaction then it will create a mutual benefit in a long run. It can be concluded that CRM is an aspect that creates a long-run relationship that leads to mutual benefit, as long as the CRM strategy is implemented effectively.

* Paper Info: Received: January 23, 2017

Accepted: March 20, 2017

* Corresponding author:

E-mail: intan.sakti@widyatama.ac.id

Affiliation: Universitas Widyatama, Indonesia 
Innovation is a process that changing new ideas become new useful products. Innovation also can be referred as a process transforming opportunities into ideas. Innovation comes from simple ideas, as long as it is something new and something that is better than the existing. At the same time, the innovative capability of an entrepreneur is a process changing opportunities into saleable ideas. To become a person with a good entrepreneurship spirit then one should have creativeness and innovativeness. Successful entrepreneurs use particular strategies by making unique products and services with new innovations. Their uniqueness making them different from others, so they don't assume any other companies as competitors.

If an entrepreneur wants to be a success in their business, then he will make products with new innovations. This condition occurs because products and services without innovativeness won't be developed, therefore the business won't run properly. Tardiness of innovation in products or services brings changes in autonomy (Schumpeter, 1951).

According to West (1997), innovation is: "An introduction to a new way in doing things at work. Innovation does not imply absolute renewal, and changes can be regarded as an innovation if the changes itself is considered as something new for a person, group, or organization. Innovation can be varied from the small one to the most important one". Carnegie and Butlin (1993), define innovation as something new or enhanced that is made by a company in order to create a significant added value that is beneficial directly or indirectly. One of the determinants of innovation is the challenge in the organization's environment because an organization with innovation emphasizes quality. Managerial support towards innovation also plays an important role in the organization when all the individual of organization would like to develop and implementing ideas related to the new ways of doing things. Developing innovation at work started with developing individual creativity, whereas new ideas come from motivation, thoughts, and implementation of individuals at work. Based on the explanation above then we can conclude that innovation capability is an exploitation of new ideas to be a success. Interaction among initiators, implementers, and users could become a dynamic mechanism where the transfer of value among feedforward and feedback innovations occurs. According to Geralis and Terziovski (2003), this innovation ability providing potential effective innovation.

Innovation is closely related to Customer Relationship Management (CRM). CRM is a strategy which is conducted by a company or market players to build, manage, and strengthen good relationship between consumers or customers with organizations, the aim is to build customer's loyalty towards the product. In practice, this strategy covers all service treatment aspects to customers, including call center, sales, marketing strategy, technical support, and all the field workers who work directly related to customers.

In general, the function of CRM is to put consumers and the market players in the same row. That's why the CRM concept supposed to draw customer's attention and enhancing their attachment towards the developed product's brand. Besides that, another function of CRM is a connector between a company and costumers to find out what are customers' needs and wants. This function also can help company to determine problems. The company needs these functions to learn the market environment and to watch the growth of the competitors.

An entrepreneur is someone who runs his private business with profit or loss possibilities. Therefore, an entrepreneur should be prepared for loss or big profit. Entrepreneurs also should have some of these characteristics such as confidence, ambitious, adventurous, agreeable, have many interests, and like to try something new.

This entrepreneurial spirit could be raised through formal education in college or training outside schools which are better to be addressed to youth (college students).

This has to be done because college students need many other things to be capable of the degree behind their names. With the entrepreneurship ability, they will be more confident to live their life, and also at least they will have their own business and won't be unemployed. 


\section{Method}

We use questionnaire instrument for the data collection in this study. The sampling method is probability sampling with simple random sampling technique. The population is all the Marketing students' year 2012, and the calculated sampling is 100 respondents. With the Likert scale, we made 5 marking score: $1=$ Strongly Disagree, 2=Disagree, 3=Neutral, 4=Agree, 5=Strongly Agree. The model used in this study is causality model with the SEM (Structural Equation Modelling) equation, while we use Lisrel version 8.5 for the data processing. This is an explanatory research which is causality explains a connection between variables through the hypotheses calibration (Ghozali, 2008). We chose this type of study because the goal is to explain the relationship and influence between variables.

Based on the hypotheses, we determine the variables used in this study. There are three variables, which are Innovation Capabilities, Customer Relationship Management, and Young Entrepreneurs. We use observation, interview, and questionnaire for the data collection and the analysis tools are descriptive and quantitative. We use SEM for the data analysis.

\section{Result}

The result of the study which has been processed by SEM can be seen in the picture below:

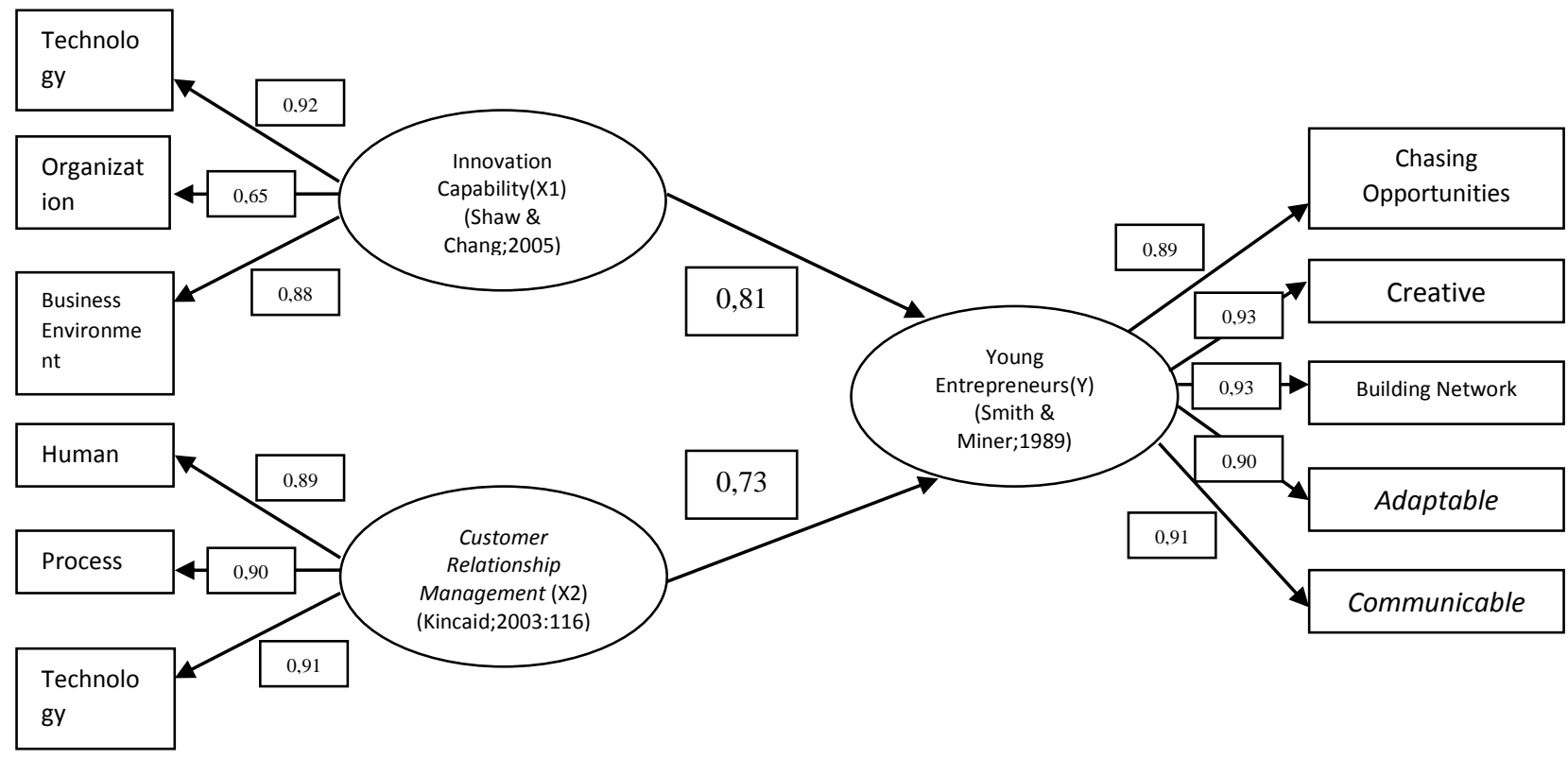

Figure 1. The Results

The figure above explains three variables (innovation capability, CRM, young entrepreneur) has been researching showed which variable did have strong influence and weak influence. From the result of examine using SEM we already knew by seeing the number. We can imagine that if all of those students in college having these skills then they do not have to worry about being jobless after graduate, consider that is mostly happen in our country (Indonesia). Also, we can see that innovation is key being an entrepreneur that the source it is from creativity. So, they will need tools (place) to resource, stimulate and sharpen the creativity which in their campus. A lot of ways; change curriculum, change teaching strategy, facilitating the students, etc. 


\section{Discussion}

From the analysis and explanation using SEM, then we can conclude that Innovation Capability and CRM have a big influence towards young entrepreneurs. Those variables also stimulate them to sharpen their business intuition. Overall, we hope that the implementation could be supported by the related institution so that the graduates could maintain their entrepreneurial spirit to start their own businesses. Which is if this successfully happens, then all of the graduates will help government and nation to increase the growth of the economic.

\section{References}

Carnegie, R. and Butlin, M. (1993), Managing the innovating enterprise, Australian companies competing with the worlds best. Business Council of Australia, Innovation Study Commission.

Ghozali, Imam. (2008). Aplikasi Analisis Multivariate dengan Program SPSS. Edisi Keempat. Semarang: Badan Penerbit Universitas Diponegoro.

Kotler P.T. \& Keller K.L. (2009) Marketing Management, (15th Ed.) Prentice Hall, USA.

Luk, C.L., Yau, O.H.M., Tse, A.C.B., Sin, L.Y.M., \& Chow, R.P.M. (2005). Stakeholder Orientation and Business Performance: The Case of Service Company in China. Journal of International Marketing. 1069031X. Vol.13.

Schumpeter, J. (1951). Change and the Entrepreneur. Jakarta: Gramedia Pustaka Utama.

Geralis, M., \& Terziovski, M. (2003). A quantitative analysis of the relationship between empowerment practices and service quality outcomes. Total Quality Management \& Business Excellence, 14(1), 45-62.

West, M.A. (1997). Developing Creativity in Organisations. Wiley-Blackwell 